\title{
https://doi.org/10.5817/NR2021-1-7
}

\section{Tři knihy ze Siedlc ${ }^{1}$}

БЛАШКIB, O., MNICH, R. (red): Освальд Шпенглер и славяне. Коллективная монография. Opuscula Slavica Sedlciensia, tom XIII, IKRiBL, Stowarzyszenie im. Franciszka Karpińskiego. Siedlce: Opuscula Slavica Sedlcensia. Institut regionalnoj kultury i literaturovedčeskich issledovanij im. Franciška Karpińskogo v Sedl'cach, 2020.

KOZAK, E., BORKOWSKA, A. (red.) (2020): Исповедь и проповедь в культуре и литературе. Conversatoria litteraria XIV. Siedlce - Banská Bystrica.

БЛАШКIB, О., MNICH, R. (red): Феномен русской эмиграции. Коллективная монография. Siedlce: Instytut Kultury Regionalnej i Badań Literackich im. Franciszka Karpińskiego, 2020.

I když se personální sestava siedlckého pracoviště za poslední léta přece jen změnila, zůstává tu jeho široké pojetí slavistiky, v jejímž centru stojí rusistická bádání - klíčovou roli tu hraje i nyní ve Varšavě na univerzitě působící Roman Mnich, jeho žena Ljudmila, ale i další, kteří editují různé sborníky a kolektivní monografie. Nebudu komentovat, zda jsou nebo nejsou v protežovaných databázích, ale obsahují podněty, jejichž hodnota zůstává trvalejší, než bychom si mysleli. Tři svazky, které se tu recenzují, o tom výmluvně svědčí.

První se zabývá delikátním spojení klíčového díla Oswalda Spenglera a slovanského světa, zejména Ruska, nebot právě jemu věnoval německý myslitel řadu pozoruhodných pasáží své knihy Zánik Západu (překládá se různě, ale, jak správně kdysi upozornil M. C. Putna, jde spíše o klesání, pokles, sestup Západu - Der Untergang des Abendlandes). Na samém počátku knihy je rozhovor o v podstatě čerstvé knize rakouského autora o Spenglerovi („Вместо предисловия: Девять вопросов об Освальде Шиенглере к Петеру Штрассеру [Peter Strasser], автору книги Spenglers Visionen. Hundert Fahre Untergang des Abendlandes (Wien 2018"): „Ist das heute vorherrschende „rechte“Interesse an Spenglers Gedanken nicht ein Interpretationsproblem? Ist Spengler ein ,rechter', gar ein faschistischer Philosoph? Hat er angesichts seiner Beziehung zum Dritten Reich nicht eine ganz andere Richtung repräsentiert? Spengler war gedanklich ein Vertreter der Konservativen Revolution - mit dem Unterschied, dass er nicht daran glaubte, mit dem Rückblick in die eigene Geschichte eine kulturelle, Renaissance; etwa des Feudalismus und des Königtums von Gottes Gnaden, einleiten zu können. Aber er

1 Tento výstup vznikl na Masarykově univerzitě v rámci projektu Mezislovanské kulturní a literární vazby číslo MUNI/A/1331/2020 podpořeného z prostředkủ účelové podpory na specifický vysokoškolský výzkum, kterou poskytlo MŠMT v roce 2021. 
verabscheute eben, wie so viele andere Gebildete und Halbgebildete, alles Demokratische und Liberale, auch die Menschenrechtsnormen und den Gedanken, wonach alle Menschen ,gleich'seien. Spengler verabscheute den Völkerbund. Dass er sich dann weigerte, für den Austritt der Nationalsozialisten aus jener zwischenstaatlichen Friedensorganisation eine publizistische Rechtfertigung zu liefern, hatte mehrere Gründe. Spengler stand in Distanz zu den Nazis, er fand die hemmungslose Hetze gegen das fudentum degoutant, weil pöbelhaft. Vor allem jedoch war ihm Hitler noch immer zu sehr abhängig von seiner Partei, der ,Nationalsozialistischen Arbeiterpartei, die nach außen hin so tat, als ob sie eine große kulturelle, weltbewegende Idee zu verkörpern und zu realisieren hätte. Das alles widersprach Spenglers Prophetie-Modell des Untergangs: zunächst die Apokalypse, die totale Zerstörung der todesmüden Zivilisation, und dann erst, wie Phönix aus der Asche, eine neue ,Kultur." [BLAŠKIV, MNICH 2020b, 11-12].

Tyto úvodní pasáže obsahují (ještě i v dalších částech) vše podstatné, co je spojeno s nadčasovým významem Spenglerovy knihy i s narůstajícím zájmem o ni dnes. Kromě závěrečné práce editora Romana Mnicha je klíčovou studií Закат Европы или модерн? germanisty Nikolaje Rymara (roč. 1945), rodáka z Rigy, který se etabloval studiemi o (západo)německé literatuře (zde by se jeho úvahy o tzv. západoněmeckém románu z roku 1979 daly srovnat s podobnými opusy české germanistky Květuše Hyršlové, roč. 1929, např. raný Západoněmecký poločas 1945-1960, vyd. Čs. spisovatel, Praha 1963) o poetice, teorii románu apod., absolventa Lotyšské státní univerzity (1971), aspiranta ve Voroněži a nakonec doktora věd (1993) a profesora (1998) v Samaře (dřive Kujbyšev), špičkového ruského filologa / literárního vědce. Rymar' spojuje Spenglerovo úsilí demonstrovat kulturu jako fenomén, který má dávat smysl lidskému životu i smrti, s prací Györge (Georga) Lukácse Theorie des Romans (1915-1920). Tento prrístup ke kultuře jako jakémusi prafenoménu nebo prasymbolu vede ke snaze objevovat celistvost, holismus kultury. Rymar' Spenglera pokládá za kulturologického tradicionalistu, jak tyto jevy prezentuje historická poetika (tu se odvolává na jiného ruského teoretika literatury Samsona Brojtmana). Spenglerův „Zánik“ třeba traktovat nikoli jako přechod do stadia civilizace, ale jako vznikání a tvarování moderny, tedy jiného typu kultury, která je dána také jiným typem osobnosti. To vše obsahuje i všemožný pokrok (Fortschritt), zejména technologický, ale také protiklad individualistické osobnosti a potřeby lidského společenství, pěkně česky „pospolitosti“, což vede $\mathrm{k}$ ztrátě smyslu bytí. Zdůvodnění individuálního lidského bytí dnes ztrácí $\mathrm{v}$ kultuře své zdůvodnění. Moderna by mohla vést $\mathrm{k}$ hledání a nacházení rovnováhy mezi těmito dvěma krajnostmi, ale podle mého soudu sem zasahuje i změněná osobnost dnešního člověka daná patrně pokračující evolucí nebo genetickými zásahy. Ruské slovo „модерн“ znamená tu německé „die Moderne“; Rymar” není ostatně náhodou germanista, ale v ruském kontextu je obvykle spojováno jen se secesí (nyní často i „сецессион“; „сецессия“ si uchovává pouze význam „oddělení, „odštěpení bez 
souvislosti s tím, že umělecký směr má stejnou etymologii), ale to bude jistě procházet dalším vývojem (lat. modernus = proudící, současný; pojem údajně vznikl v pozdní antice jako protiklad „antiquus“, tedy starý, dávný, přizpo̊sobený novým proudům).

$\mathrm{V}$ druhé stati souboru se autor těchto řádků zamyslel nad českým kontextem Spenglerovy klíčové knihy, kde ukázal na specifikum českého postavení mezi Německem a Ruskem.

Natalja Grozdeckaja (Moskva) se ve svém lingvodidaktickém výzkumu zabývá obrazy Eddy a probuzení „faustovské duše“ v Spenglerově díle. Dina Magomedovová (Moskva) přesvědčivě ukazuje na ruské prameny Spenglerovy koncepce Zániku Evropy ve známé stati A.Bloka Ztroskotáni humanismu (Крушение гуманизма, 1919), ale také předtím N. Danilevského, N. Punina (ruský kunsthistorik, muž Anny Achmatovové, obviněný r. 1935 spolu s jejím synem Lvem Gumiljovem z teroristického protisovětského spiknutí, uvězněný a omilostněný spolu s ním J. V. Stalinem na přímluvu Borise Pasternaka) nebo P. Lavrova; ukazuje se, že knihu Danilevského Rusko a Evropa (1869) Spengler znal právě v rozhodující převratné době ruského a světového vývoje (1917-1920). Tat’jana Kuzovkinová (Tallinn) v podnětné studii ukazuje na vliv Spenglerových idejí na Jurije Lotmana (dopisy z fronty) a jeho pojetí semiosféry a na to, že zejména pozdní dílo Lotmanovo a jeho vztah k Spenglerovi by měl být středem dalšího odborného zájmu.

Marija Poljakovová (Moskva) prezentuje objevnost Spenglerova př́stupu k civilizaci a konci světových kultur pro historicko-pedagogický proces. Gennadij Loveckij a Vitalij Bessonov (Kaluga) pojednávají o turbulentnosti a hlediscích bifurkace světového historického procesu v dílech Oswalda Spenglera a Dmytra Čyževského, koeditor Roman Mnich se $\mathrm{v}$ hluboce koncipovaném závěrečném pojednání vrací k ruské recepci Spenglera, např̀ v díle Alexeje Loseva nebo Michaila Bachtina, ale dívá se také na jeho spojení s dneškem: „Наследие Освальда Шпенглера, конечно же, мы не сможем понять без оглядки в прошлое, но это наследие одновременно открыто будущему в смысле поставленных вопросов и нерешённых проблем. Гуманитарные науки, в отличие от наук точных, живут повторяемостью актов понимания и интерпретаций, повторяемостью смыслов. В таком повторении и в новой интерпретации, очевидно, нуждаются сегодня и концепции немецкого философа.“ [BLAŠKIV, MNICH 202ob, 266]. To je přesně to, proč se dnešní člověk vrací k dávným myšlenkám a knihám: není nic tak starého, aby v naukách o člověku nenabývalo nové aktuálnosti, jak to kdysi ostatně ve známé větě vyjádřil $M$. Bachtin hovořící o „velkém čase vzkříšení pozapomenutých obsahů.

Spengler a jeho Zánik Západu má mnoho hran a odrazových ploch. Na jednu jsem poukázal v reflexi české recepce, ohlasovosti a kontextuálnosti; jinak se na něj dívají Rusové s jinými tradicemi a nezatížení úsilím o národní a státní svébytnost, „trpící“ však fixní ideou svého mesianismu (vzpomeňme na Gorbačovovu knihu 
s příznačně velikášským názvem Přestavba a nové myšlení pro naši zemi a pro celý svět / Перестройка и новое мышление для нашей страны и для всего мира, 1987), podobně jako Poláci, jinak v prostředí německém s hlubokými tradicemi filozofie, včetně Naturphilosohie a filozofie vůle, jinak na evropském Západě a v anglosaském Novém světě, ale i zemích románské kultury i jinde. Nepochybně zajímavé by bylo, jaká byla a je reflexe Spenglera v Asii, třeba v Číně, už vzhledem $\mathrm{k}$ její tisícileté tradici myšlení o civilizaci a kultuře a jejich transcendencích. Možná se takové úvahy ještě někdy objeví.

Kniha o kazatelské a zpovědní literatuře, tedy homiletické a konfesionální, obsahuje různé prŕispěvky řady autorů. Jak je tato vrstva nebo žánrové seskupení terminologicky nejasné, dokazuje príběh s termínem „проповедальность“, který ruský korektor nechtěl uznat jako ruské, i když je ho dnes plný internet: patrně to souvisí s jinými tradicemi východního a západního křestanství a jinou pozicí literatury a jejích žánrů. Naše stat z úvodu Исповедалность, проповедальность и мемуарная литература ukazuje v řetězcích př́ípadových studií na souvislost středověké žánrové tradice se současnou dominantní vrstvou literatury. Viktorija Pičutina (Moskva) analyzuje roli církve a divadla v pozdní antice, Marija Poljakovová (Moskva) ukazuje na Lutherových kázáních implementaci jeho vzdělávací soustavy. Viktorija Kokonova (Moskva) rozebírá kázání portugalského jezuity Antonia Vieiry o indiánech a černošských otrocích, Olga Dovgij (Moskva) objevuje v Kantěmirových satirách rétorický režim kázání, což je ovšem známé konkrétně i obecně, mj. z knih Tatjjany Avtuchovičové a Renate Lachmannové, jež se týkají funkce poloskryté rétoriky v struktuře novodobé literatury. ${ }^{2}$ Duchovní Alexej Čornyj z pravoslavné moskevské univerzity se ve svém článku zabývá rozporem mezi vládnoucí mocí a péčí o duši (господственная власть vs. душепопечение) ve zpovědní praxi ruské tradice synodálního období (obvykle 1700-1721, kdy byl metropolitou Stefan Javorskij): názorně demonstruje postupy a taktiku politické moci ve vztahu k církvi a složité vnitřní rozpory sekulárního a sakrálního.

Často, jak známo, převažuje názor, že politická emigrace Rusů mimo Rusko začala až ve 20. století, dílem už po první ruské revoluci (tu však přerušila carova amnestie z roku 1913 na počest tř́ století Romanovců na ruském trůně) a hlavně po Velké ř́ijnové, tedy bolševické revoluci, zhruba po občanské válce v letech 1920-1922. Andrej Možajskij (Moskva) v objevném pojednání analyzuje memoáry jednoho významného emigranta 19. století (byla jich však řada, chvilku jím byl i Petr Jakovlevič Čaadajev váhající s návratem do Ruska po neúspěchu povstání z prosince 1825 a přesvědčený až vychovatelem carových dětí Vasilijem Andrejevičem Žukovským, čehož možná vícekrát litoval, nejvýraznější pak Nikolaj Ivanovič Turgeněv, 1789-1871,

Viz naše recenze: [POSPÍŠIL 1995; POSPÍŠIL 1997]. 
Alexandr Ivanovič Herzen/Gercen, 1812-1870, Nikolaj Platonovič Ogarjov, 1813-1877, a Michail Alexandrovič Bakunin, 1814-1876; zajímavou postavou byl ruský jezuita Ivan Sergejevič Gagarin, 1814-1882, nejstarší syn proslulého vysokého státního úředníka Sergeje Ivanoviče Gagarina, z proslulé knížecí rodiny, v mládí kamarád homosexuálního knížete P. V. Dolgorukého, s nímž v Sankt-Petěrburgu nějakou dobu bydlel, zapletený do aféry Puškinovy manželky a do celého příběhu tragického básníkova souboje, ruský diplomat a katolický konvertita, člen Societatis Iesu, v Pařiži zakladatel Cyrilometodějské společnosti, s nímž se v Paříži při svém pobytu v 6o. letech 19. století setkával novinář a spisovatel N.S. Leskov, a další), všichni, jak vidno, vrstevníci, a nachází v nich zajímavě modifikované prvky zpovědi. Vladimir Sergejevič Pečérin (1807-1885) je někdy nazýván prvním ruským disidentem. Nikoli náhodou byl tento šlechtic a profesor Moskevské univerzity západnikem a byl široce respektován jako znalec starořecké a římské literatury a její překladatel, mj. Sofoklových dramat. Velmi si ho vážil ministr osvěty (v letech 1833-1849), hrabě Sergej Semjonovič Uvarov (1786-1855), také uznávaný vzdělanec, filolog, odborník na antiku, překvapivě člen Arzamasu spolu s Puškinem, jehož činnost je často nesprávně omezována na proslulou ideologickou triádu pravoslaví - samoděržaví - národnost (jen těžko přeložitelné slovo, značící národní ráz, ale také „lidovost“; do angličtiny se např. „народность“ překládá jako nationality, folkness, national character, nationalism, nationalness aj.). Pečérin odjel na zkušenou do Berlína, jehož univerzita byla v tehdejší Evropě centrem vědy, stejně jako celé tehdejší Prusko, vrátil se do Ruska a udělal rychlou univerzitní kariéru, milován a podporován oficiální mocí: už se v něm však rodila idea emigrace, kterou později uskutečnil, stal se katolíkem a členem řeholního řádu redemptoristů, přesněji Kongregace Nejsvětějšího Vykupitele, byl pokřtěn v Lutychu (Liège, Luik, Lüttich), potom se usadil ve Velké Británii, kde se setkával s Gercenem a Ogarjovem, nakonec skončil v Irsku jako představitel dublinské církevní školy a katolický bojovník proti protestantismu. Jeho životem a dílem se v 70. letech 20. století zabývali irští rusisté, byl značně populární v SSSR v 3o. letech minulého století, kdy vyšly některé jeho práce. Autor se věnuje jeho epistulárním memoárům Замогильлные записки (vyšly v Kalininu, od roku 1990 opět Tver, roku 1932), obvykle vydávaným s dodatkem Apologia pro vita mеa, Оправдание моей жизни. Pozapomenutý Vladimir Pečérin byl klíčovou postavou ruského 19. století jako skutečný Evropan značného rozhledu, filolog a znalec antiky, který současně doložil neudržitelnost ruského politického systému: nesnášel ani dusné prostředí Moskevské univerzity naplněné intrikami.

Anna Popovová (Doněck) zajímavě zkoumá genderové aspekty v zpovědi muže v konfesionálním románu Alfreda de Musset a mladé divky u George Sandové ( $L a$ Confession d'un enfant du siècle, 1836, a La Confession d'une jeune fille, 1864; u Sandové, jež tolik ovlivnila české spisovatelky 19. století, se spekuluje o jejím příbuzenském vztahu s Jiř́m z Poděbrad). 
Další studie pokrývají poměrně rozsáhlou tematickou vrstvu se značnou metodologickou variabilitou: Natalja Volodinová (Čerepovec) zkoumá filozofickou zpověd’ v Turgeněvově povídce Довольно/Dost, Jelena Andruščenková (Moskva) analyzuje kazatelské a zpovědní prvky u D. S. Merežkovského, podobně Julija Jegorovová prezentuje toto spojení na Gorkého Zpovědi, jiné studie rozebírají zpovědní elementy u symbolisty a katolického konvertity Vjačeslava Ivanova. Lidija Jeninová (Jekatěrinburg) zkoumá naivisty-dělníky, budovatele závodu na Urale z pozice identity a individuality (тождественность и самость), Olga Kulaginová (Moskva) pojednává o kazatelství u Jacquesa Préverta; z varií uvádíme jen rozhovor Ruslana Šošina z Varšavské univerzity se známým konzervativním spisovatelem Alexandrem Prochanovem (nar. 1938): jeho názory se nebudou každému líbit, ale za přečtení tento rozhovor stojí i z hlediska obecných rysů ruského vývoje (Российская история всегда была имперской); parafrázuje zde názory ze své knihy Поступь русской победы (2012).

Monografická koncepce kazatelství a konfesionality se ukázala jako nosná: prezentovala literaturu takříkajíc $\mathrm{z}$ druhé strany, akcentovala spojnici se středověkem, nepř́mo tak potvrzujicí teze Berdajevovy knihy Новое средневековье (Berlin 1924), manifestovala postsekularitu 21. století, tedy jistý přerývaný návrat $\mathrm{k}$ sakralitě obohacené o sekulární pochybnost.

Třetí kniha není nijak rozsáhlá, i když pojednává o fenoménu, který za posledních 30-40 let zaplavil rusistický svět, z něhož jsou už všichni unaveni, nebot' se asi 30-40 let jeví jako konjunkturální. Nicméně právě tento svazek ukazuje, že je možné na problematiku ruské emigrace pohlédnout $\mathrm{i}$ jinak, a potvrdit tak oprávněnost koncepce emigrantologie, kterou kdysi na mezinárodním sjezdu slavistů v Krakově roku 1998, jehož závěry včetně některých projektů zhatil odpor slavistických konzervativců, vytyčil tehdejší předseda Mezinárodního komitétu slavistů Lucjan Suchanek (nar. 1937), a zase objevně a svěže, s filozofickým podložím. Emigrace je tu chápána jako modus vivendi: mnoho z toho naznačuje již úvod editorů (Мне подменили жизнь... и я своих не знаю берегов).

Emigrace jako způsob existence: Leonid Heller/Geller píše o svém otci Leonidovi, jenž v Paříži spojoval ruskou a polskou emigraci, z jiné strany o něm píše Jędrzej Piekara; Olga Pčelinová sleduje fenomén ruského zahraničí komplexně jako soubor těch, kteří chtěli představovat celé Rusko; Walentyna Krupowies studuje ruský pařǐžský emigrační fenomén jako kontrast společného a svého, Viktor Dimitrijev poukazuje na působení filozofie Henriho Bergsona v ruské emigraci, o nenapsané knize Dmytra Čyževského (Dmitrije Čiževského) Schiller v Rusku pojednává Ljudmila Fuks-Šamanskaja, pozornosti pochopitelně neušel ani Boris Poplavskij jako hvězda ruské emigrace $\mathrm{v}$ eseji Jeleny Tyryškinové (Novosibirsk), stranou nezůstal ani zajcevovský a šmeljovovský diskurs ve studii Zoji Kucové z Lodže; najdeme tu i analýzu 
čtvrté vlny emigrace, autor této recenze přispěl pojednáním o polyfunkčnosti ruské literárněvědné emigrace v meziválečném Československu, speciální oddíl monografie je věnován Zinaidě Hippius/Gippius(ové) a Dmitriji Merežkovskému.

Olga Blinovová ukazuje ruské zahraničí jako embryonální stadium androgynního boholidstva v povídkách a publicistice právě Zinaidy Hippius/Gippius(ové) období emigrace, Oxana Chripunkovová se dívá na pojetí Érota v díle obou manželů, Andrej Gordin sleduje scénickou realizaci Merežkovského dramatiky (Riga), Vjačeslav Krylov prezentuje osud klasika Lva Tolstého v emigrantské kritice Zinaidy Hippius/Gippius(ové).

Třetí oddíl je cele věnován Vladimiru Nabokovovi a uvádí ho studie grodněnské profesorky Taţjany Avtuchovič(ové) o proslulých Nabokovových přednáškách o ruské literatuře jako metatextu, Tatjjana Kazarinová zkoumá subjektovou organizaci románu Ada aneb Žár (Ada, or Ardor. A Family Chronicle), Anastasija Krjukovová se zase věnuje jeho románům Oтчаяние/Zoufalství a The Pale Fire / Bledý oheř, Žosefina Kušnirová píše o apokatastasi v románu Lužinova obrana v souvislosti s třetí časovou osou / časovým úsekem / Achsenzeit Karla Jasperse a idejemi Nikolaje Berdajeva. Na jedné straně se mi zdá reálnější blízkost k problematice Mozarta a Salieriho (Puškin), ale současně mě zarazila souvislost tzv. politiky humanismu pro 21. století s Jaspersem a Berdajevem: vzpomněl jsem si na masochismus (tak jsem to tehdy chápal) filozofů 90. let 20. století, kteří chtěli demonstrativně rezignovat na filozofické systémy a velké ideje z obavy, aby nebyly zneužity, jak se to stalo ve 2o. století nejednou. Nakolik je tato souvislost mezi Nabokovem, Mozartem a Salierim, Jaspersem, Berdajevem a projektem humanismu 21. století jen náhodná a nakolik je záměrná, ponechejme na čtenáři a jeho mentalitě.

Ukazuje se, že emigrace, hlavně politická, cílená, a nutnost přežít v novém prostředí v několikerých tlacích, může vyvolat nové ideje vzniklé právě „vtlačením“ původních představ do soukolí nových poměrů. Někde je to zcela patrné, například u Nabokova, jinde méně nápadné, jako tomu bylo u Hippius/Gippius(ové) a Merežkovského, někde se rodí jiná dimenze jako u Poplavského, někde je snaha udržet status quo - nejen Ivan Šmeljov nebo Boris Zajcev, ale hlavně Ivan Bunin, o němž tu překvapivě - snad kromě několika odkazů - není nic nebo jen málo.

Tři knihy $\mathrm{v}$ podstatě $\mathrm{z}$ jednoho hnízda a jedné docela mladé tradice: siedlcká rusistika soustředila dnes kolem sebe - byt již v poněkud rozptýlené podobě výkvět polské, ruské a také dílem ukrajinské a běloruské rusistiky a přitáhla i některé další z jiných zemí, zejména střední Evropy. Zvláště koncentrace ruských rusistů, kteří žijí v Rusku nebo mimo ně, souběžně napojení na západoevropská centra a hlavně akcentace nejen Moskvy, ale především jiných center, což byla vždy - často vynucená - síla ruského literárněvědného bádání (vzpomeňme na Bachtinův Saransk, na Kemerovo, Doněck, Samaru, Jekatěrinburg, Nižnij Novgorod, Iževsk, kdysi také 
Daugavpils s Cilevičem nebo Tartu s Lotmanem), to se nyní daří v siedlckých edičních sériích, za nimiž často stojí proslulý Roman Mnich napojený na Německo a Rakousko. Jakkoli mohu mít námitky $\mathrm{k}$ lecčemus z komentovaných bádání (to slovo mám raději než „výzkum“ a „badatel“ je v humanitních a filologických vědách přiléhavější než „výzkumník“, nebở je v něm obsažena ona spekulativnost, hloubavost), třeba k něčemu z výroků Petera Strassera z úvodního rozhovoru nebo k některým zjištěním Natálie Gvozděcké, k řadě věcí $\mathrm{z}$ ruské emigrace, např. k rozborům Nabokovových románů, zejména Ada or Ardor nebo k Zinaidě Hippius, podobně jako k něčemu ze svazku o kazatelství a konfesionalitě, kde se tyto rysy hledají někdy až př́iliš umanutě, je po čase zážitkem číst tolik koncentrovaných idejí, úvah, dobrodružství myšlení v dnešní značně vyprázdněné době, v níž se osobnosti vytrácejí a, jak jsme se docela nedávno právě na poli literární vědy znovu přesvědčili, stávají se chtěnými zajatci komerce a médií, a ideje jsou vytvářeny spíše $\mathrm{k}$ likvidaci nosných tradic než $\mathrm{k}$ jejich rozvoji a přeměně. Siedlcké knihy jako by dodávaly literární vědě obecně a rusistice a slavistice zvláště novou naději a také to, čemu Nietzsche ve svých skvělých aforismech říkal „radostná věda“" (Die fröhliche Wissenschaft, 1882).

Ivo Pospíšil

\section{Bibliografie:}

BLAŠKIV, O., MNICH, R. (red.). (2020a): Fenomen russkoj èmigracii. Siedlce.

BLAŠKIV, O., MNICH, R. (red.). (202ob): Osval'd Špengler i slavjane. Siedlce.

KOZAK, E., BORKOWSKA, A. (red.) (2020): Ispoved' i propoved' v kul'ture i literature. Conversatoria litteraria XIV. Siedlce - Banská Bystrica.

POSPÍŠIL, I. (1995): Renate Lachmann, Die Zerstörung der schönen Rede. Rhetorische Tradition und Konzepte des Poetischen (Theorie und Geschichte der Literatur und der schonen Künste, Band 93, neue Folge - Reihe A Hermeneutik - Semiotik - Rhetorik, Band 8, München 1994, 370 S.). Wiener Slavistisches Jahrbuch, Band 41, Wien 1995, S. $296-298$.

POSPÍŠIL, I. (1997): Rétorika a ruský román. (Tat'jana Jevgen'jevna Avtuchovič: Ritorika i russkij roman XVIII v. Vzaimodejstvija i načal'nyj period formirovanija žanra. Grodno 1995, 185 s.). Svět literatury 1997, 13, s. 116-119. 